\title{
Krakowska kamienica jako przykład domu w mieście. Funkcjonowanie i życie krakowskich kamienic przełomu XIX i XX w.
}

\section{A Cracow tenement house as an example of a house in the city. Functioning and life of Cracow tenements at the turn of the 19th and 20th centuries}

\begin{abstract}
Streszczenie
Kamienice miały duże znaczenie w Krakowie i pełniały ważne funkcje. Nie tylko pełniły rolę moralną i polityczną. Były stałym miejscem zamieszkania. Jednak w XIX w." dom w mieście "stanowił jeszcze jedną sferę- rodzinną. Był miejscem egzystencji i spotkań, wyrazem zamożności jego mieszkańców. Taki przykład domu wzorcowego był niewątpliwie właściwy mieszczańskiemu życiu prywatnemu. Występował on w licznych wariantach, różniących się niezliczonymi szczegółami. Możemy mówić o względnej jedności mody życia mieszczańskiego w XIX w. i sposobów zamieszkiwania wzmocnionej stylami architektonicznymi. Przedmiotem moich rozważań będzie złożone społecznie, bardzo różnorodne środowisko kamienicy, które tworzyło odrębny świat. Opierając się jednak na licznych wspomnieniach, na publicystyce prasowej, można starać się odtworzyć rozkład, strukturę społeczną oraz życie codzienne mieszkańców. Kwestia architektury mieszkalnej XIX-wiecznych miast była szeroko badana, ale mało powstało do tej pory prac łączących aspekt architektoniczny ze społeczno-obyczajowy.
\end{abstract}

\begin{abstract}
The tenement houses were very important in Cracow and played important functions. They not only played a moral and political role. They were a permanent place of residence. However, in the nineteenth century, "house in the city" was one more sphere - family. It was a place of existence and meetings, an expression of the wealth of its inhabitants. Such an example of a model house was undoubtedly a good bourgeois private life. He appeared in numerous variants, differing in innumerable details. We can talk about the relative unity of fashion of bourgeois life in the nineteenth century and ways of living reinforced by architectural styles. The subject of my deliberations will be a socially complex, very diverse environment of a tenement house that created a separate world. However, based on numerous memories, on press journalism, one can try to recreate the distribution, social structure and everyday life of the inhabitants. The issue of the residential architecture of 19th century cities has been widely studied, but so far few works have been created connecting the architectural aspect with social and moral aspects.
\end{abstract}

Słowa kluczowe: kamienica, historia społeczna XIX w, mieszkania

Key words: tenement house, social history of the 19th century, housing

Etymologia słowa „kamienica” według „Słownika języka polskiego, to „murowany dom mieszkalny o kilku piętrach i wielu mieszkaniach". Nie jest to jedyne określenie. Mianem „kamienicy” można również określić mieszkańców zamieszkujących tego typu budynek. Dom miejski tworzył szczególny rodzaj społeczności. Musiał mieć ściśle zdefiniowany podział na część „publiczną" oraz „prywatną". Wynikało to z fundamentalnej zasady prawa miejskiego.

Na przełomie XIX i XX wieku Kraków w dużym stopniu odzyskał swój blask. W wielu dziedzinach miasto nawiązało do okresu największej swej świetności. Kraków choć nie spełniał funkcji stolicy autonomicz-
The etymology of the word "tenement" according to the "Dictionary of the Polish language" is a "brick house with several floors and many flats". This is not the only term. The "tenement house" can also be used to describe residents living in this type of building. The townhouse created a special kind of community. He had to have a strictly defined division into the "public" and "private" parts. It resulted from the fundamental principle of city law.

At the turn of the 19th and 20th century, Krakow regained its splendor to a large extent. In many areas, the city referred to the period of its greatest splendor. Although Krakow did not act as the capital of autono- 


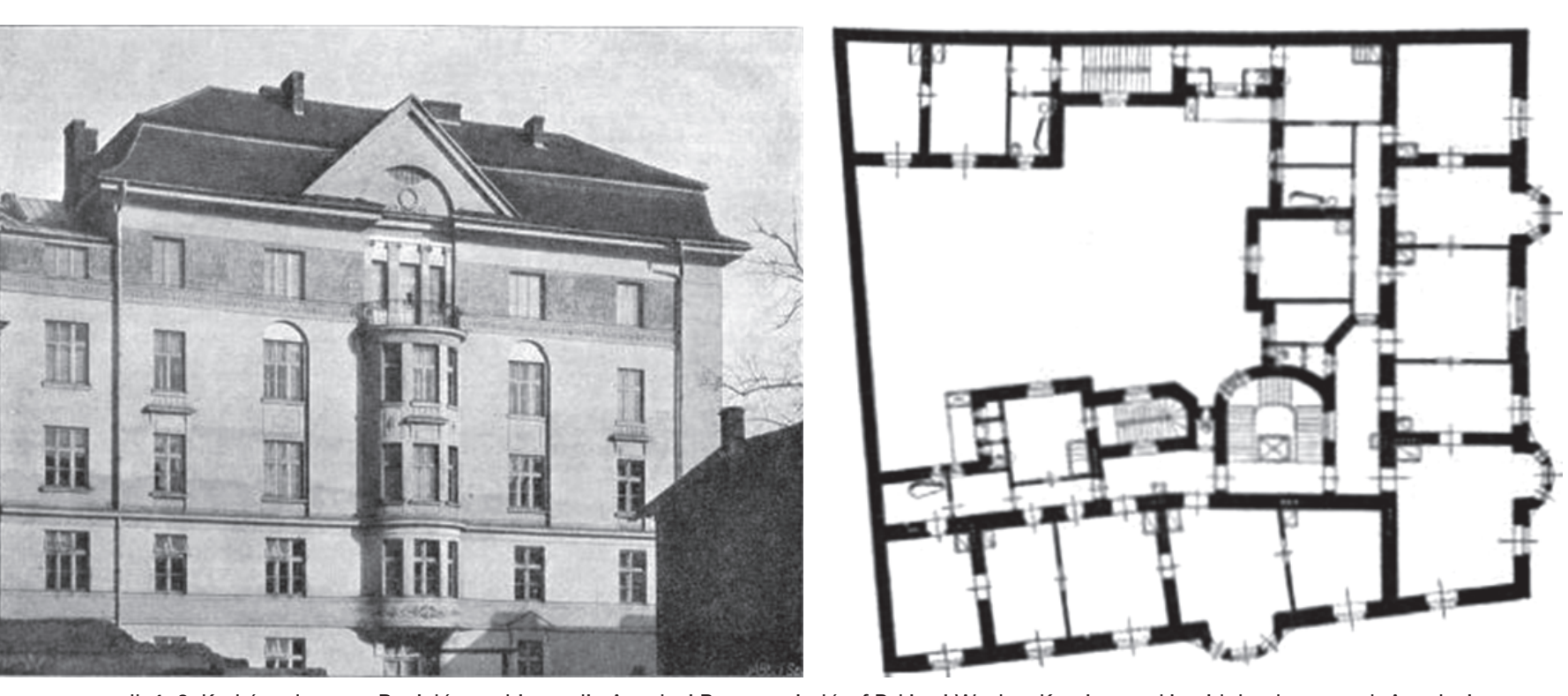

II. 1, 2, Kraków, dom pp. Popieló́w u zbiegu ulic Asnyka i Basztowej: Józ
I pietra. Architekt, Rok XIV , Zeszyt 2, ilustr.-s. 31-32, Kraków, luty 1913

nej Galicji, stał się znacznym ośrodkiem życia umysłowego. Polityka rządu austriackiego pozwalała na nieskreppowany rozwój nie tylko naukowy, kulturalny,
ale także polityczny. $Z$ tak nakreślonym obrazem kontrastowa rozwoj gospodarczy miasta. W końcu XIX wieku mieszkańcy Krakowa odczuwali dotkliwie brak mieszkań. Krakow jako ośrodek "polskości" przyciągal Polaków praktycznie ze wszystkich trzech zaborów. Stał się niekwestionowaną duchową stolicą Polaków co miało także swoje konsekwencje w uksztattowaniu jego oblicza społeczno-politycznego. Dominując rolę w miescie odgrywały inteligencja i ziemiaństwo. Dopiero na kilka lat przed pierwszą wojną światow wzrosła aktywność polskiego mieszczaństwa związanego $z$ handlem i rzemiosiem, ale wzajemne animozje i podzialy nie pozwolimy te j grupie spolecznej stać się rownorzędnym partnerem w lokalnych rozgrywkach politycznych. Granice dzielące ziemie polskie przez caly wiek XIX skutecznie odbily się na charakterze rozWojowym poszczegónych dzlelnic.'

wa ulegał zasad(yiek w WIX. Gród "Kzy w miasto dziewietnastowieczne z licznymi kamiencami, parkami i siecia komunikacyina Na poczatku omawianej epoki Kraków stał przed poważnymi problemam w zakresie budownictwa. Miasto w obrebie fortyfikaci miało budowe zwarta jednak wiele obiektów było bardzo zniszczonych. Jedną z ważniejszych decyzii dla przeobrażenia urbanistycznego było wydanie dekretu, o zburzeniu średniowiecznych murów miejskich.'Podjeto również prace nad czẹściową regulacją ulic. $W$ drugie połowie XIX wieku nastąił regres $\mathrm{w}$ rozwoju prze strzennym miasta. Przekształcając miasto $w$ twierdz ograniczano inwestycje budowlane, szczególnie wokó mous Galicia, it became a significant center of intellectual life. The policy of the Austrian government allowed unhampered development not only to be scientific, cultural, but also political. With such a picture, the city's economic development contrasted with it. At the end of the 19th century, the inhabitants of Kraków were severely affected by the lack of housing. Cracow as a center of "Polishness" attracted Poles from virtually all three partitions. It became the undisputed spiritual capital of Poles, which had its consequences in shaping its socio-political face. Intelligence and landed gentry played the dominan role in the city. It was only a few years before the First sie related to trade and craft increased, but mutua animosities and divisions would not allow the socia group to become an equal partner in local politica competitions. The boundaries dividing the Polish lands throughout the 19th century effectively affected the development character of particular districts The character of Cracow's residential development underwent fundamental changes, especially in the changes in a typical city - a fortress in a nineteenthcentury city with numerous tenement houses, parks and a communication network. At the beginning of the discussed period, Cracow faced serious problems in the field of construction. The city within the fortifications had a compact structure, however, many objects were badly damaged. One of the most important decisions for the urban transformation was the issuance of 2. Work was also undertaken on the partial regulation of streets. In the second half of the ninete World War that the activity of the Polish bourgeoi19th century. The "Krak" castle was an example of a decree on the destruction of the medieval city walls centrum. ${ }^{3}$ Zmiany które nastąpiły po 1867 roku przyniorozwoju. Złagodzono szereg dotkliwych przepisow budowlanych. Dokonywano lączenie mniejszych parcel oraz modyfikowano ukła funkcjonalny staromiejskich kamienic. Liczba rodzi pozbawionych własnego mieszkania spadła do $15 \%$. Zauwazalne było większe bogactwo w opracowani form architektonicznych. Spuscizną minionego stulecia była również zieleń, która stanowiła w twierdzy ele ment maskowania. Charakterystyczne dla Krakowa było systematyczne podnoszenie zabudowy do wysokosci drugiego i trzeciego piętra. Tendencja do podwyzszania zabudowy miast Galicji najsininiej uwidoczniła się w Kraco wigzan $z$ ograniczon liczba parceny parterowe ze wzgledu nastiejace trudności w rozszerzanu granc miasta Po 1900 roku koniunktur budowlana ulegta zaheme morzadowe stanety przed problemem zapewnienia mistu wolnych parcel budowlanych. Jedynym wyiściem była zabudowa poza dotychczasowe granice miasta. Inicjatorem koncezcii Wielkiego Krakowa" zostat ówczesny prezydent miasta dr Juliusz Leo. Od 1 kwietnia 1910 roku mógł przystapić do praktycznej realizacij swoich planów.

Pod koniec XIX w. staje się widoczna zmiana typu budownictwa mieszkaniowego: $z$ domów wyłącznie zamieszkałych przez właścicieli, na kamienice czynszowe. Interesujący obraz przedstawia struktura wielkości krakowskich mieszkań. Były to raczej małe mieszkania o niskim standardzie, choc czynsze nalezały do najdroż szych w monarchii. ${ }^{5}$ Niezwykle korzystne było wynajmowanie przez kamieniczników części parterowej domow firmom handlowym lub usługowym. Własciciele domów dokonywali licznych przerobek na parterze w celu wydzielenia lokali mogących pomiescic handel. Opłacalne było równiez wynajmowanie lokali instytucjom państwowym. Systematyczne podnoszenie cen parcel budowlanych stworzyly znakomite warunk spekulacji budowlanych i czynszowych. Kamienicz nicy chcąc nadrobic poniesione koszty budowy bądż kupna kamienicy, podnosili czynsze. W konsekwencj własnośc nieruchoma stanowila obiekt pożądania we wszystkich zamożniejszych warstwach społeczności

W wieku XIX miasto rozwijato sie pod wpływem zacazkalych go rodzin zlemianskich. Obok nich rezyCzartoryskich Tarnowskich. Również po powstaniu styczniowym osiadta szlachta kresowa. Tylko nieliczn z nich kupowali whasne domy. W 1890 roku w rekach ziemian w Rynku Gtównym było 15 kamienic czyli az $34 \%$ wszystkich domów o charakterystycznym położe niu: siedem po stronie potudniowej, sześć na zachodniej, jedna na pótnocnej i jedna na wschodniej. ${ }^{87}$ arówno po stronie północnej i wschodniej Rynku koncentrowa sie głównie handel Śródmieście było dzielnicą w które była położona większość pałaców. Wymienić można kamienice Jana Popiela przy ul. św. Jana. To w tym domu miejskim odbywały się słynne "czwartki" skupiające naukowców i literatów. ${ }^{9}$ Posiadanie własnego domu miej- there was a regression in the spatial development of struction investments were limted, especially around the center ${ }^{3}$. The changes that took place after 1867 brought the city new development prospects. A number of severe building regulations have been eased. Smaller plots were combined and the functional layout of the Old Town tenements was modified. The number of families deprived of their own home fell to $15 \%$. There was a greater wealth in the development of architectural forms. The legacy of the past century was also greenery, which was in the fortress element of masking. Characteristic for Cracow was the systematic raising of buildings to the heights of the second and third floors. The tendency to increase the deveopment of the cities of Galicia was most pronounced in Cracow. Firstly, single-storey houses were eliminated, which resulted in a limited number of construction plots due to the existing difficulties in expanding the city's borders. After 1900, the construction downturn was halted due to the lack of free plots. Local government authorities faced the problem of providing free building plots to the city. The only solution was to build buildings beyond the existing city limits. The inithator of the "Grand Cracow" concept was the then city president, Dr. Juliusz Leo. From April 1, 1910, he could proceed to the practical implementation of his plans At the end of the 19th century, a change in the type of housing construction is visible: from houses excluAn in inhabing by the owners, on tenement houses. An incresting picture presents a structure of the size Af Cracow apartents. These were rather small apartthe most a lows expen comm commercial or senice compaties by tena ts. Homecor to separe pround

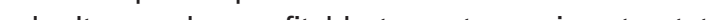

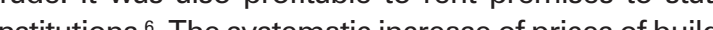
plos cre texce ding for the costs of building or buying a tenement house, hey rased their rents. Consequently immovable propstrata of the Cracow commesity 7 .

In the nineteenth century, the town developed under the influence of the landowners who lived there. Old magnate families - the Lubomirski, Czartoryski and Tarnowski princes lived with them. Also after the January Uprising the border nobility settled down. Only few of them bought their own homes. In 1890, in the hands of landowners in the Main Square there were 15 tenement houses, that is $34 \%$ of all houses with a characteristic location: seven on the south side, six on the west, one on the north and one on the east ${ }^{8}$. Both on the northern and eastern sides of the Main Market Square, mainly trade was concentrated. The city center was the district where most palaces were located. You can name Jan Popiel's tenement house 
skiego było ważnym udogodnieniem zwłaszcza dla dzieci włascicieli ziemskich. Przez większa częsc roku były posyłane do szkơ i na pensje. Taki dom spełniał jeszcze jedną ważną funkcję, mianowicie przynosit dochód z wynajmu części mieszkań.

W połowie XIX W. fasady kamienic uległy zmianom Upraszczano kompozycje, powściągliwie używano dekoracji formalnych. Stosowane motywy neogotyckie i neoromańskie $w$ drugiej połowie XIX w. ustępowały historyzmowi i eklektyzmowi ${ }^{10}$ Zamówienia architektoniczne były realizowane przez wykształconych i utalen towanych architektów. Sródmieście Krakowa stanowiły kamienice czynszowe, które zajmowały około $80 \%$ zabudowy mieszkalnej. Rrzykladem obszernej kamienicy Projekt Popielów ú zbiegu ulicy Asnyka i Basztowej. Dom miejsi posiadat cztery pietra i nievizyzowe poddasze oraz dwa skrzydta frontowe i ficyne miczkalna. Wewnatrz znaidowat sie obszerny dziedziniec. Gtónn. klatka schodowa posiadała dźwig osobowy Obok niej zaprojektowano również gospodarcza klatke schodowa zaprojekn z kuchnia i pomieszczeniami gospodarczymi. Na pietrze zaprojektowano dwa duze mieszkania które posiadały wewnętrzny korytarz, oddzielony od mniejszych wewnetrznych korytarzy gospodarczych. Reprezentacyjne pokoje posiadały połączenie amfila dowe. Wykusz trójboczny wzbogacał salony. Miesz kania wykończone zostały w wysokim standardzie zaopatrzono je $w$ łazienki i pomieszczenia sanitarne. Dwa dwupokojowe lokale posiadające pomieszczenia mieszkalne oraz przedsionek i łazienki zlokalizowano w oficynie. Architekci w formach nawiązali do baroku i neoklasycyzmu. ${ }^{12}$

Zycie domów w mieście stanowity swoisty mikroswiat. Każda kamienica posiadala swoj klimat wplywający na obyczaje lokatorow. Życie spoleczne to czyło się w dwoch sferach: publicznej - mężczyzn prywatnej - kobiet. Lącznikiem tych sfer był salon najbardziej reprezentacyjny pokoj w całym domu. Posiadanie salonu był symbolem przynależności klasowej. To w nim przyjmowano gości czy eksponowano zbiory kolekcjonerskie i pamiątki rodzinne. Często ży cie rodzinne organizowano wedfug przestrzeganych schematow. Podobne pomieszczenia mogly pelnic różne funkcje $w$ zależnosci od rodzinnych tradycji. z różych pom stata kobieta Dobra organizatorka korzystato nie tylko z pomocy stużby ale też z podreczników savoirvivre'u. Szczególnie duż wage przywiazywano do popołudniowych obowiazków towarzyskich, przyj mowano gości lub oddawano" wizyty. Wieczoram umilano swój czas, czesto haftowano, dziergano czy malowano do sztambuchów. ${ }^{13}$ Ujecie uptywajacego czasu ujawniało sie w prowadzeniu swoich osobistych pamiętników. ${ }^{14}$ Mężczyźni choć często przebywali poza domem, mieli swoje własne miejsca. Jed nym $z$ ważniejszych pomieszczeń $w$ kamienicy by gabinet-typowo męskie pomieszczenie, w którym pan domu pracowat czy przyjmowat swoich gości w interesach. Często pomieszczenie służyło do przecho- at ul. St. John. It was in this townhouse that the faentists and writers ${ }^{9}$. Owning your own townhouse was an important convenience especially for children of landowners. For most of the year, they were sent to schools and for salaries. Such a house fulfilled on more important function, namely it brought income fom renting some of the flats.

In the mid-19th century, the facades of the tenement houses changed. Compositions were simplified, formal decoration was used with restraint. The neo-Gothic and neo-Romanesque motifs used in the second half of the 19th century gave way to historicism and eclecticism ${ }^{10}$. Architectural orders were implemented by educated and talented architects. Center of Cracow was tenement houses which occupied about $80 \%$ of residential building '. An example of a spacious tenement house was '. Ane Popiels' house at the intersection of Asnyka and Pakies and Wactaw Kryżect was made by Jozef Pad four floors and a noz-unows. The towy wings and a residentia oubuilding Inside the frow aspacious courtyard. The main staircase had a pas enger lift. Above it was also designed an economic the kirchen and utily rooms. Two large apartments were designed on the first floor, which had an internal corridor, separated from smaller internal corridors. Representative roms had an enfilade connection. The three-sided bay window enriched salons. The apartments were finished to a high standard, they were equipped with bathrooms and sanitary rooms. Two two-room flats with living quarters and vestibules and bathroom were located in the outbuilding. Architects referred to Baroque and neoclassicism in their forms ${ }^{12}$

The life of houses in the city was a kind of microworld. Each tenement house had its own climate influencing the tenants' customs. Social life took place in two spheres: public-men and private-women. The link between these areas was the living room, the most representative room in the whole house. Having a salon was a symbol of class affiliation. It was in him that guests were received or exhibited collections an family souvenirs. Often family life was organized according to the patterns followed. Similar rooms could have different functions depending on family tradme of the day or year. The woman was the guard of the rhythm of everyday life. The good organizer benfited not only from the help of the service but also from the savori-vivre books. Particularly great attention was paid to afternoon social duties, guests were received or 'visits were given'. In the evenings, their ime was greatly appreciated, often embroidered, knitted or painted in scrapbooks ${ }^{13}$. The presentation of the passing time was revealed in the conduct of his personal memoirs 1 . The men, though often outside portations in the tenementhousewas as wywania cennego księgozbioru, podkresiające wyksztalcenie i polityczne obycie właściciela. Na przetomie XIX/XX w. krakowskie kamienice stanowią odzwierciedlenie ówczesnych waru ków społecznych i ekonomicznych. Były mie scem egzystencji i spotkan, wyrazem zamożności jego mieszkańców. Możemy mówić o względn jedności mody zycia mieszczañskiego w XIX w. ia wzmocnionej stylam architektonicznymi

PRZYPISY

K. Karolczak, Wtaściciele domón w Krakowie na przetomie

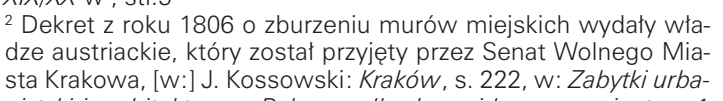

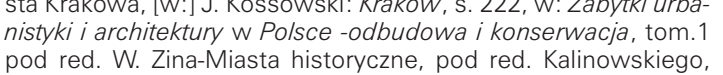
pod red. W. Zina-Miasta historyczne, pod red. Kalinowskiego,
Warszawa 1986 Zagodnie $z$ teoria obozón warownych, miast musiato przyjać
armie liczacaca nawet 100 tysiecy żotnierzy dlatego zakazano za-

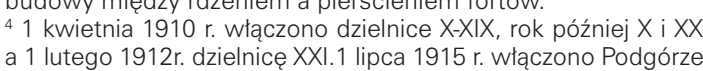
5 Wysokość czynszu
standardu i lokalizacj

b́ra kiedyś pethila funkcje bramy wja W Wszechnie zabudowywana i przeznaczona na lokal kupiecki.
"K.Karolczak, Wtasciciciele domón w Krakowie na przetomie XIX

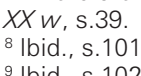

Z.Biatkiewicz, Przemiany architektury krakowskiej w potowie

"Mozzna wyodrebnićc cztery typy układów krakowskiej zabudowy szernych mieszkan, 5-b konaygnacy,ne z oficynami ki" mieszczacce 1-2 mieszkania z ogrodem. Wedtug Janusza Bog
danowskiego: Problemy urbanistycznei rewalorzzacii zabudow mieszzaniowej z przetomu XIXIXX w. na prykktadzie Krakowa, (W:]

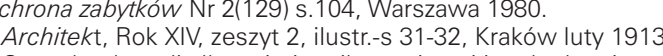
13 Sztambuch czyl album-imiennik Z wpisami i malunkami.
14 S. Wasyleswki, Zycie polskie w XIX wieku , s.219-223, Kraków
1962

LITERATURA

Architekt, Rok XIV, zeszyt 2, ilustr-s 31-32, Kraków luty 1913 r,

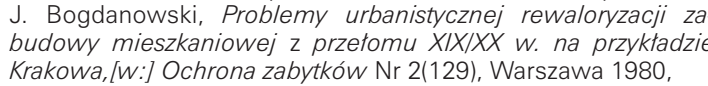
J. Bogdanowski, Warownie izieleń twierdzy Kraków, Wydawn . Biatkiewicz, Przemiany architektury krakowskiej w potowie

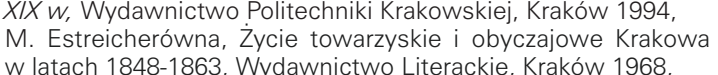
W latach 1848-1863, Wydawnictwo Literackie, Krakow 1968 ,
Historia życia prywatnego praca zbiorowa pod redakcia M. PerHistoria Życia prowatnego praca abiorowa pod redakciaj M. Per-
rot, Zaktad Narodowy im. Ossolinskich, Wroctaw 1999 ,
Koie XIXI

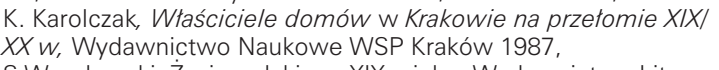
S. Wasylewski, Zycie polskie w XIX wieku, Wydawnictwo Litera

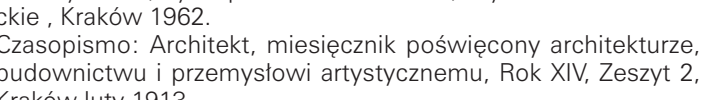

ically a men's room, in which the master of the house worked Often the room was use to store a valuable book collection, emphasizing the owner's education and political presence.

At the turn of the 19th and 20th centuries, Krakow's tenement houses reflect the contemporary social and economic conditions. They were a place of existence and meeting an expression of the wealth of its inhabitants. We can talk about the relative unity of fashion of bourgeois life in the

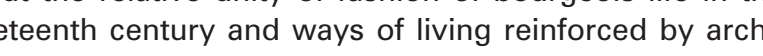
tectural styles.

ENDNOTES

of the 19 th / 20 th century The decree of 1806 on the demolition of the city walls was issued by the
Austrian authorities, which was received by the Senate of the Free City of ning and architecture in Poland - reconstruction and conservation, vol. 1
edited by W. Zin-Miasta historyczne, edited by Kalinowski, Warsaw 1986 3 According to the theory of fortified camps, cities had to host an army of
up to 100,000 soldiers, which is why it was forbidden to build between the

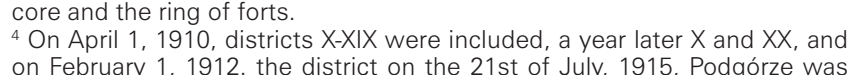
inclue ${ }^{6}$ The hallway which once served as as the entrance gater, leading to the einner
courtyard, in the second half of the nineteenth century, commonly built and intended for the merchant's premises.
7 K.Karolczak, Homeowners in Cracow at the turn of the 19th / 20 th century p.39.
8 lbid., P.101
9 lbid, P.102

10 Z.Bialkiewicz. Changes of Cracow's architecture in the mid-19th century. pp. $81-93$.
11 It is possible to distinguish four types of layouts of Krakow's residentia

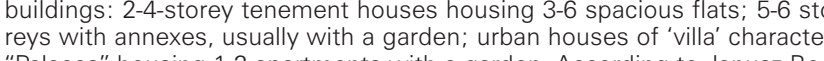
"Palaces" housing 1-2 apartments with a garden. According to Janusz Bog-
danowski: Problems of urban renovation of residential housing from the
turn of the 19 th $/ 2$ th th century on the example of Krakow, [in:] Protection of monuments No. 2 (129) p. 104, Warsaw 1980. 1913 .
${ }_{13}^{13}$ Stambuct, or album-namesake with entries and paintings

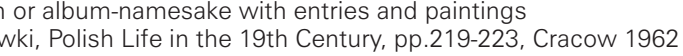

BIBLIOGRAPHY

Architect, Year XIV, notebook 2, illustrations-s 31-32, Cracow, February 1913 ,
J. Bogdanowski, Problems of urban revalorisation of residential buildings
from the turn of the 19 th / 20 th century on the example of Cracow, lini from the turn of the 19 th $/ 20$ th century on the example of Cracow, lin-
Protection of monuments No. 2 (129). Warsaw 1980 , $J$. Bogdanowski, Warawnie and greenery of the fortress Krakow, literary
publishing house, Cracow 1979, Z. Biatkiewicz, Transformation of Cracow architecture in the mid-19th centu-
ry, Cracow University of Technology Publishing House, Cracow 1994, ent
W. Estreicherónna. Escort and social life of Krakow in the years 1848-1863. ry, Cracow University of Technology Publishing House, Cracow 1994,
M. Estreicherónna, Escort and sociail life of Krakow in the years 1848-1863,
Wydawnictwo Literackie, Cracow 1968, The history of private life, collective work edited by M. Perrot, National Insti-
tute. Ossolískich, Wroctaw 1999 ,
K Karolczak Homeowners in Krakow at the turn of the 19 th / 20 th century K. Karolczak, Homeowners in Krakow at the turn of the 19th / 20 th century,
Scientific Publisher WSP Cracow 1987 ,
S. Wasylewski, Polish Life in the 19th Century, Wydawnictwo Literackie, Cra-

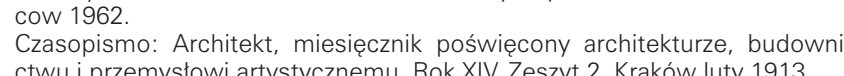

